\title{
Legislation and Comparison with Some International Laws
}

\author{
Valentina Triolo*, Antonina Argo , Stefania Zerbo and Paolo Procaccianti \\ University of Palermo, Department of Legal Medicine, Institute of Legal Medicine, Palermo, Italy \\ Via del Vespro 127, 90129 Palermo, Italy
}

\begin{abstract}
AIDS, acronym of Acquired Immune Deficiency Syndrome, is a clinical picture related to Human Immunodeficiency Virus (HIV) infection. In the last 20 years this infection has had a high and progressive diffusion. Generally, the HIV antibody tests (ELISA plus RIBA methods) are used to revealed the infection. In this paper, the Authors present the HIV testing in Italian legislation and the comparison with some international laws, particularly for the minors. In most European and American Countries this test is volunteer and for minors is not require the consent of parents; in Italy the implementation of the test is today governed by the law 135/1990. This law establishes that the conduct test is volunteer and the informed consent is obligatory; but nothing is said about the consent of the child. The actual Italian law about the minor consent for us is unsatisfactory. The international experience can be useful to change or supplement the current Italian act.
\end{abstract}

\section{Introduction}

AIDS is a clinical disease related to Human Immunodeficiency Virus (HIV) infection. In the last 20 years this infection has had a high and progressive diffusion. The estimated number of adults living with HIV worldwide in 2007 was 30-34 million. Children under 15 years was 2,5 million [2,2-2,6 million]. In the same year the number of deaths due to AIDS was about 2 million. Every day, more than over 6800 persons become infected by HIV and more than 5700 persons die of AIDS, mostly because of inadequate access to HIV prevention and treatment services (Figure 1).

Generally, the HIV antibodies tests (ELISA plus RIBA methods) are used to reveal the infection [5].

In most European Countries this is a volunteer test (e.g. Austria, Denmark, France, Belgium) [2]; in Italy today the implementation of the test is governed by the act $135 / 90$.

The art. 5 of this act states that the conduct test is volunteer and the informed consent is obligatory; but nothing is said about the child's consent.

Art. 5: "None can be subjected to analysis for determine HIV infection without his consent, if not for the clinical need in his interest. The analysis of HIV infection are permitted, as part of epidemiological programs, only when the sample is anonymous .... The communication of the results of tests for direct or indirect HIV infection can be provided only to the same person".

Therefore, the test must be absolutely voluntary and the informed consent is very necessary. Also, the informed consent isn't obligatory for "clinical necessity and the interest of the patient". However, it isn't clear what are "the need clinics".

In this paper, we treat the issue of consent about the test for HIV and particularly for "minor" person (in our system, the minor person is less than 18 years) in comparison with some international laws.

\section{About the consent}

The Italian Constitution establishes always the Right to health and the voluntary nature of care (art. 32 cost.).

Also, the deontological Italian code (C.D.) of physicians (art. 33, 35), December 2006, establishes that all medical treatments are always volunteer.
The art. 33 c.d. states that "the physician should provide to the patient the most appropriate information for diagnosis, prognosis, the prospects and possible alternative diagnostic-therapeutic and foreseeable consequences of the choices. The physician must assess his capacity of understanding, in order to promote maximum participation in decision-making and adherence to the proposed diagnostic-therapeutic. [...]”.

The art. 35 c.d. states that "the physician should not perform diagnostic and / or therapeutic activities without the explicit and informed consent of the patient. ...".

The Oviedo Convention for the Protection of Human Rights and dignity of the human being (Convention on Human Rights and Biomedicine - 4 April 1997) has been ratified in Italy with the act 28 march $2001 \mathrm{n}^{\circ} 145$. This convention (art. 5) states that "a medical intervention cannot be made only after informed consent of the patient. Adequate information must be given about the purpose and nature of the intervention and its consequences and its risks. [...]".

In conclusion, the quality and not quantity of information it is always a priority; also the informed consent is always obligatory.

The minor's consent

Further reflections should be made in the case of the minor's consent.

In the case of minors (art. 37 c.d.), the consent must be expressed always by the legal representative; also the physician (art. 38 c.d.) must consider the will of the child in relation to his age, his ability to understand and his maturity [3].

*Corresponding author: Valentina Triolo,University of Palermo, Department of Legal Medicine, Institute of Legal Medicine, Palermo, Italy, E-mail: dr.valentinatriolo@ hotmail.it

Received December 08, 2010; Accepted December 28, 2010; Published December 30, 2010

Citation: Triolo V, Argo A, Zerbo S, Procaccianti P (2010) Legislation and Comparison with Some International Laws. J Forensic Res 1:108. doi:10.4172/2157 7145.1000108

Copyright: @ 2010 Triolo V, et al. This is an open-access article distributed under the terms of the Creative Commons Attribution License, which permits unrestricted use, distribution, and reproduction in any medium, provided the original author and source are credited. 
The art. 37 c.d. states that "in the case of minor ... the consent to diagnostic and therapeutic interventions must be expressed by the legal representative ... the physician is obliged to provide adequate information to the child and to consider his will, in relation to the age, the comprehension and the maturity of the subject ...".

The Oviedo Convection states also (art. 6) that "in accordance with the act, when a minor does not have the capacity to consent to an intervention, the consent cannot be done without the permission of his legal representative, authority designated by act. The opinion of a child is considered as an increasingly important determinant, depending on the child's age and level of maturity". This act does not exclude the consent of the child, but it is not explicit. This convention describes only the conditions under which it is certain that the child cannot give its consent.

Significant differences are found in Spanish and French legislations about the consent of minors [1]. The art. 9 (paragraph 3) of Spanish Act 41/2002 establishes the need for consensus of the legal representative when the child isn't emotionally and intellectually capable of understanding the scope or nature of medical treatment. We note that this act refers to no only intellectual nature, but also emotional conditions. The emotional conditions is very important factor particularly in the case of HIV testing.

The Spanish legislator also distinguish minors of 12 years for which the consent of the legal representative is required, and greater than 16 years or emancipated minors, for which the consent of the legal representative is not required. In the case of risk, the physician must always informed the legal representative.

The children between 12 and 14 years not have the right to choose for themselves.

Also, it is very important the role of physician; he must assess the ability of the child.

In the French legislation [Code de la santé publique Article L. 11115 : " Par dérogation à l'article 371-2 du code civil, le médecin peut se dispenser d'obtenir le consentement du ou des titulaires de l'autorité parentale sur les décisions médicales à prendre lorsque le traitement ou l'intervention s'impose pour sauvegarder la santé d'une personne mineure, dans le cas où cette dernièrs'oppose expressément à la consultation du ou des titulaires de l'autorité parentale afin de garder le secret sur son état de santé. Toutefois, le médecin doit dans un premier temps s'efforcer d'obtenir le consentement du mineur à cette consultation. Dans le cas où le mineur maintient son opposition, le médecin peut mettre en oeuvre le traitement ou l'intervention. Dans ce cas, le mineur se fait accompagner d'une personne majeure de son choix. Lorsqu'une personne mineure, dont les liens de famille sont rompus, bénéficie à titre personnel du remboursement des prestations en nature de l'assurance maladie et maternité et de la couverture complémentaire mise en place par la loi n• 99-641 du 27 juillet 1999 portant création d'une couverture maladie universelle, son seul consentement est requis], the authorization to care by legal representative isn't necessary if the treatment is required in order to ensure the health of the child. Also, the child have right to express dissent to treatment.

In America the children have the possibility, regardless of age, to take decisions about the HIV antibody test and they have the right not to inform their parents.

Particularly, in New York State the capacity to consent to an HIV test is determined without regard to age. Informed consent for minors varies, depending upon the minor's situation.
The capacity to consent is defined in the Public Health Law as the "ability, determined without regard to the individual's age, to understand and appreciate the nature and consequences of a proposed health care service, treatment, or procedure, or of a proposed disclosure of confidential HIV related information, as the case may be, and to make an informed decision concerning the service, treatment or disclosure". (Public Health Law Section 2780.5). Clearly, the minor may not have this capacity to decide; in this case, it is necessary the parental consent.

The physician should conduct an individualized assessment of minor's ability to understand the nature and consequences of HIV testing and his results.

Also the new guidelines published in September 2006 by Centres for Disease Control and Prevention (CDC) (Morbidity and Mortality Weekly Report September, 2006) address the voluntary HIV testing indifferently to persons ages 13 to 64 .

Then, parental consent is not needed to tests minors for HIV and the result are delivered to minor, not to parents.

This recommendations establish that HIV testing must be informed and voluntary, but the specific written consent to HIV testing is not necessary.

The general consent to medical care should be sufficient also to HIV testing and "prevention counselling should not be required as a part of HIV screening programs in health-care settings".

We believe that the specific written consent is very important to strengthen the relationship between physician and patient, as such the pre-counselling is very need to choice of the patient.

The specific information is indispensable especially in cases of negative results.

Without specific information about the implication of negative result, the patient could believe that they are not at risk. The HIV antibodies testing are positive after about six months by infection; in this time the result could be false negative.

In addiction, the informed consent can avoid potential liability in malpractice.

Even in the Californian legislation the children have the full right to allow some treatments without the information of parents or legal representatives (Cal. Health and Safety Code $* 121020)$. In this case, however, the minor must be greater than 12 years. It not needs to assess their ability to understand.

The health care provider is not permitted to inform a parent or legal guardian without minor's consent. The provider can only share the minor's medical records with the signed consent of the minor.

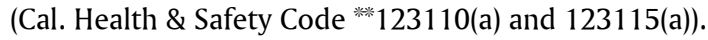

In 1988, the Florida Legislature was adopted HIV/AIDS legislation [6]. This legislation is based on nationally accepted public health guidelines, including education for a wide variety of individuals, testing requirements, significant exposures and confidentiality of HIV test. No person can perform an HIV test without first obtaining the informed consent of the test by patient or her legal representative.

The physician may examine and treat a minor for HIV without parental consent. The Florida Law forbids telling parents of the minor's HIV test results without the minor's consent. However, the provider must assess whether the minor has the capacity to understand the risks and benefits of the test or treatment. 
Citation: Triolo V, Argo A, Zerbo S, Procaccianti P (2010) Legislation and Comparison with Some International Laws. J Forensic Res 1:108. doi:10.4172/2157-7145.1000108

Page 3 of 3

\section{Consideration}

In Italy the child is not allowed to decide without the consent of parents; although the deontological code establishes the obligation of physician to take account the will of the child. The "taken into account the will" does not authorise to inform the child without the parents.

We believe that it should recognize exceptions, as already in special conditions such in the acts of the interruption of pregnancy (act n..$^{\circ}$ 194/1996) and contraception (act n. ${ }^{\circ}$ 194/1978).

Those acts establish that the physician should take only will of minor patient, after preliminary assessment the maturity of the child and his age.

In Italy the voluntary interruption of pregnancy is regulated by the act $n .^{\circ} 194 / 1996$. The art. 12 establish that the woman younger than 18 years have the right to interruption pregnancy in the first 90 days also without the consent of parents, but with the authorization of the Judicial Court.

The act 194/78 in art. 2 about the contraception in the minors states that "the administration ... the drugs in order to responsible parenthood is also allowed to minors". This article does not explain whether it is necessary to inform the parents, but the consent of parents isn't obligatory.

These acts therefore recognize the right to the child to consent. We believe that this right should be recognized also to HIV antibody test; particularly, because issues of children's consent is lack in the act $135 / 90$.

The making of HIV antibody test connects the much personal sphere of a child; therefore it should require special protection.

First of all, we must make a distinction between mayor (14-18 year-old). and small children ( $<14$ year-old). To decide even without parental consent is possible only for mayor minors.

Then, the procedure should be divided into several moments (Figure 2).

It should need a preliminary meeting to minor information about the test currently available, the risks associated with testing, the significance of the results.

This time is a pre-counselling; it is very important moment in order to make aware the child for an informed choice.

Also, at the first meeting the physician should evaluate the degree of maturity and understanding of the child, in order to determine whether or not it is capable of making decisions to performing the tests without the parents.

The physician must evaluate (see also reference the Spanish act L. 41/2002) the psychological, cultural, social and economic factors $[4,8]$. It is need also investigating possible alternatives for the child and the consequences of the information to the parents or legal representative.

The physician should assess also the emotional ability of the patient to receive information in the case of a positive test.

It is also possible that in non-emergency cases may be useful conducting more meetings with child.

If it is necessary the parent's consent, it may be disagreement between the choices of parent and child, particularly about the prophylaxis; in this case, the physician should consider the will of minor or/and require Court authorization (Judge Child).

Next time, in case of positive test, the physician should conduct further evaluation in order to assess whether or not the patient is able to make decisions to follow treatment. It may be necessary the support of the parents from the therapy.

The minor may be unable to manage treatment and any complications of therapy.

In any case (positive or negative results), the doctor should provide information about possible contagion to other persons and about prevention of future infections.

In conclusion, about consent to HIV antibodies testing of children, we think that the minor should have the right to consent especially when they are more than 14 years-old.

However, the physician must inform the minor about testing risks, results and sexual education; he may decide to inform his parents if the child is not able to take future decisions in case of a positive result of HIV antibodies test.

The removal the required parental consent may be advantageous.

For example, in the Connecticut Department of Public Health during the period October 1, 1991 and through September 30, 1993 is conducted the investigation to assess the change in use of HIV testing after removal of the parental consent [6]. This investigation noted that the number of minors receiving antibody tests increased after removal of parental consent requirement.

The Authors revealed that States that impose barriers to testing on minors need to re-examine their efforts. In addition, imposing barriers to minors reduce the control of epidemic infection in an at risk population.

However, it is always necessary an extensive counselling and prevention education.

In conclusion, the actual Italian law about the minor consent for us is unsatisfactory. The international experience can be useful to change or supplement the current Italian act.

\section{References}

1. Cacace $S$ (2004) Legge spagnola 41/2002 e consenso informato: cose vecchie e cose nuove. Riv It Med Leg 26: 1160-83.

2. Cattorini $\mathrm{P}$ (1996). AIDS: European legislation. Milano Istituto Scientifico H San Raffaele Europa Scienze Umane Editrice: 29.

3. Federazione Nazionale degli Ordini dei Medici chirurghi e degli odontoiatr (2006) Codice di Deontologia Medica Italy Department of Health and Human Services Centers for Disease Control and Prevention (ed) (2006) Revised Recommendations for HIV Testing of Adults Adolescents, and Pregnant Women in Health-Care Settings Morbidity and Mortality Weekly Report 14.

4. Dorn LD, Susman EJ, Fletcher JC (1995) Informed consent in children and adolescents: age, maturation and psychological state. $\mathrm{J}$ of Adolescent Health 16: $185-90$.

5. Hanssens C (2007) Legal and Ethical Implications of Opt-out HIV testing. CID 4: S232-9.

6. Meehan TM, Hansen H, Klein WC (1997) The impact of Parental Consent on the HIV Testing of Minors. Am J Public Health 87: 1338-41.

7. Riley S (2006) HIVIAIDS legal and legislative issues. HIVIAIDS Primary Care Guide.

8. Tilmans-Cabiaux C (2007) L'autonomie, une valeur-principe universelle? Exame de cas cliniques concrets en périnatologie. J Inter Bioétique 18: 25-34. 